\title{
Penanggulangan Penangkapan Ikan secara llegal di Perairan Provinsi Aceh
}

\begin{abstract}
Adwani
DATA NASKAH:

Masuk: 24 November 2018

Diterima: 24 Desember 2018

Terbit: 31 Desember 2018

KORESPONDEN PENULIS:

Fakultas Hukum Universitas Syiah Kuala, Jalan Putrou Phang Nomor 1, Darussalam Banda Aceh. Telp. (0651) 51977, fax: (0651) 52721,

Email: adwani_fh@yahoo.co.id

\section{ABSTRACT}

Countermeasure against illegal fishing in Aceh water territory has not yet run effectively as expected in accordance with the Law Number 45 of 2009 on Fisheries. This research aims to identify the policies of the local government relating to the countermeasure of illegal missing the mentioned territory. Data were collected through library research on reliable sources such as books, journals and other scholary works. In addition, field works foe collecting primary data have also been conducted through interview with relevant informen and respondents. It is found that the local government has shown necessary efforts in preventing and combating illegal fishing by issuing regulation concerning fishery issues and making coordination with relevant parties the Nary, Office of Maritime Affairs and Panglima Laot. Nevertheless, more efforts are needed including the issuance of the more specific regulation on illegal fishing which can address the case of illegal fissing by foreign fishing vessels. This is important since the existing regulation can only deal with the case of illegal fishing carried out by local fishermen with regards to illegal fishing gear and fishing permits. Keywords: Preventive, Illegal Fishing, Local Goverment
\end{abstract}

\section{ABSTRAK}

Penanggulangan penangkapan ikan ilegal (illegal fishing) di perairan Provinsi Aceh belum terlaksana secara optimal sesuai ketentuan Undangundang Nomor 45 Tahun 2009 tentang Perikanan. Penelitian ini bertujuan untuk mengetahui kebijakan-kebijakan yang telah diambil oleh pemerintah daerah terkait penanggulangan illegal fishing di perairan Provinsi Aceh. Data dalam penelitian ini diperoleh melalui penelitian kepustakaan dengan mempelajari buku-buku, jurnal dan karya ilmiah lainnya. Penelitian lapangan dilakukan dengan cara mewawancarai responden dan informan. Hasil penelitian menunjukkan bahwa pemerintah daerah telah melakukan hal-hal yang berkaitan dengan pencegahan penangkapan ikan secara ilegal dengan mengeluarkan peraturan Bupati/Walikota, Peraturan Daerah Kabupaten terkait masalah perikanan, dan melakukan pengawasan secara berkala dengan melibatkan atau berkoordinasi dengan instansi terkait, seperti TNI AL, Dinas Kelautan, dan Panglima Laot. Walaupun demikian masih dibutuhkan pengaturan khusus yang mengatur tentang illegal fishing, 
terutama yang dilakukan oleh kapal nelayan asing. Peraturan yang ada saat ini hanya dapat menjangkau illegal fishing yang dilakukan oleh nelayan lokal yang berkaitan dengan alat tangkap ilegal dan izin penangkapan ikan.

Kata Kunci: Perikanan, Penanggulangan, Penangkapan Ikan Ilegal.

\section{PENDAHULUAN}

Perairan Indonesia merupakan suatu sistem network yang terdiri dari beberapa sistem jaringan aktifitas perdagangan, politik, sosial, budaya dan lainnya. Aktifitas ini melibatkan penggunaan jalur pelayaran sebagai sarana. Konsep kemaritiman sudah dikenal sejak masa Sriwijaya sebagai kerajaan maritim terbesar di Asia Tenggara dengan kekuasaan terpusat di Selat Malaka (Thamrin, Lemhanas-RI, 16 Juni 2016: 2).

Wilayah perairan Indonesia luasnya mencapai lebih dari $5.887 .879 \mathrm{~km}$, namun nilai sektor perikanan pemasukan negara kecil. Salah satu penyebabnya adalah illegal fishing, baik oleh kapal nasional maupun kapal asing. Langkah Menteri Perikanan dan Kelautan dengan menerapkan hukum yang tegas terhadap pelaku illegal fishing pada satu sisi akan berdampak pada tumbuhnya perekonomian bangsa terutama di wilyah pesisir. Namun demikian, pada sisi lain tindakan penenggelaman kapal pelaku illegal fishing tersebut tentu dapat berdampak pada berbagai sisi, khususnya hubungnan diplomatik Indonesia dengan negara pelaku illegal fishing yang kapalnya ditenggelamkan.

Ketentuan Pasal 27 ayat (1) Undang-Undang Nomor 45 Tahun 2009 tentang Perikanan menentukan, mewajibkan setiap orang yang memiliki dan atau mengoperasikan kapal perikanan berbendera Indonesia yang digunakan melakukan penangkapan ikan di wilayah pengelolaan perikanan Republik Indonesia dan/atau laut lepas memiliki surat izin penangkapan ikan.

Pasal 76 A Undang-Undang Nomor 45 Tahun 2009 tentang Perikanan menentukan bahwa benda dan/atau alat yang digunakan dalam dan/atau yang dihasilkan dari tindak pidana perikanan dapat dirampas untuk negara atau dimusnahkan setelah mendapat persetujuan Ketua Pengadilan.

Pasal 62 ayat (2) Konvensi Hukum Laut PBB 1982 (UNCLOS), Pasal 5 Undang-Undang Nomor 5 Tahun 1983 tentang Zona Ekonomi Eksklusif Indonesia (ZEEI) disebutkan bahwa kapal asing berdasarkan perjanjian yang diadakan dapat dibenarkan menangkap ikan di ZEE. Oleh karena itu jika tidak ada perjanjian atau izin, maka tidak boleh menangkap ikan di ZEE Indonesia, apalagi di laut wilayah sangat tidak dibenarkan, namun jika terjadi diberikan sanksi hukuman atau pemusnahan berdasarkan hukum yang berlaku.

Walaupun demikian penangkapan ikan secara tidak sah banyak terjadi di perairan laut wilayah Aceh, terutama perairan Aceh Utara dan barat selatan karena airnya tenang. Pihak keamanan atau pihak terkait mengintensifkan pengamanan dengan menyiagakan TNI AL di sejumlah tempat guna pengamanannya.

Karena itu Pemerintah Daerah dituntut untuk berperan aktif melindungi segala kekayaan alam di daerahnya. Menurut Pasal 12 Undang-Undang Nomor 23 Tahun 2014 bahwa Pemerintah Daerah bertugas menyelenggarakan urusan pemerintahan yang menjadi kewenangannya, termasuk mencegah tindakan yang merugikan sumber daya ikan atau yang merugikan daerah.

Suatu hal yang terjadi bahwa pada dasarnya kapal-kapal ikan asing menangkap ikan di wilayah yang dilarang dan dengan alat-alat penangkapan yang dilarang. Demikian juga dengan nelayan-nelayan nasional yang menyalahi aturan-aturan yang berlaku. Hal demikian menunjukkan terganggunya sumber kekayaan ikan atau terkurasnya bibit-bibit ikan yang dapat dikarenakan kurang berfungsinya Pemerintah Daerah dan belum adanya aturan tertentu dalam mencegah atau menanggulangi perbuatan melanggar hukum di laut. Oleh karena itu, diperlukan suatu bentuk perlindungan melalui kebijakan yang 
dikeluarkan guna mencegah dan menghukum para pelakunya. Berdasarkan hal tersebut, menarik untuk dikaji tentang penanggulangan penangkapan ikan secara ilegal di perairan laut Provinsi Aceh.

\section{RUMUSAN MASALAH}

1. Bagaimana kebijakan pemerintah daerah dalam menanggulangi penangkapan ikan secara ilegal di wilayah perairan Aceh?

2. Bagaimana kerjasama antara instansi terkait dengan Panglima Laot dalam menanggulangi penangkapan ikan ilegal di perairan Aceh?

\section{METODE PENELITIAN}

\section{A. Pendekatan Penelitian}

Penelitian ini bersifat deskriptif analisis, yaitu penelitian yang mengusahakan untuk melukiskan fakta-fakta yang nyata dan situasi yang berkenaan dengan penanggulangan penangkapan ikan secara tidak sah, yang terindikasikan bahwa pelestarian atau perlindungan sumber kekayaan ikan itu belum terlindungi sebagaimana diharapkan. Kenyataan tersebut dianalisis secara objektif berkenaan dengan ketentuan-ketentuan terkait dihubungkan dengan teori-teori dan praktek dalam menanggulangi penangkapan ikan secara tidak sah serta berkenaan dengan alat-alat penangkapan yang dilarang.

Metode pendekatan yang digunakan dalam penelitian ini adalah yuridis normatif dan empiris, bahwa pendekatan ini dilakukan dengan mempelajari dan mengkaji kaedah-kaedah hukum yang belaku, terutama berkenaan dengan hukum laut yang digunakan dalam mencegah atau menanggulangi penangkapan ikan secara tidak sah.

\section{B. Sumber Data Dan Alat Pengumpulan Data}

Sumber data dalam penelitian ini adalah data primer dan data sekunder. Data primer yang bersumber dari berbagai kebijakan dan peraturan yang dikeluarkan bidang perlindungan atau pelestarian sumber kekayaan hayati perikanan laut. Pengumpulan data sekunder dilakukan melalui penelitian kepustakaan dengan cara mengkaji bukubuku, jurnal, hasil penelitian, konvensi dan peraturan perundang-undangan serta melalui media internet berkenaan dengan hal yang berhubungan dengan permasalahan penelitian.

Data primer diperoleh dengan melakukan Penelitian lapangan dengan cara mewawancarai pihak informan dan responden yang berkaitan dengan objek penelitian ini. Adapun yang menjadi informan dan responden seperti Kepala Dinas Kelautan dan Perikanan Provinsi Aceh, Kepala Dinas Kelautan dan Perikanan Kabupaten Aceh Utara, Kabupaten Pidie, Kabupaten Aceh Barat, dan Kota Sabang masingmasing 1 orang, Komandan Pangkalan Angkatan Laut (Danlanal) Sabang dan Para Nelayan Kabupaten/Kota, dan Anggota DPRK Kabupaten dan Kota.

\section{Analisis Data}

Data yang telah diperoleh tersebut, baik data primer dari penelitian lapangan, maupun data sekunder yang diperoleh dari penelitian kepustakaan digeneralisikan yang selanjutnya dianalisis secara kualitatif. Analisis data ini sebagai upaya mencari dan menata data secara sistematis untuk meningkatkan pemahaman peneliti tentang masalah yang diteliti dan menyajikannya sebagai suatu temuan penelitian.

\section{HASIL PENELITIAN DAN ANALISIS}

A. Kebijakan Pemerintah Daerah dalam Menanggulangi Penangkapan Ikan secara Tidak Sah di Wilayah Perairan Aceh

Daerah Aceh sebagai daerah memiliki pantai terbesar dengan letak geografis yang strategis bagi perikanan dan sebagai jalur pelayaran internasional bagi kapal-kapal asing. Di sisi lain bahwa wilayah laut Aceh memiliki potensi sumberdaya laut yang menyimpan kandungan sumberdaya hayati dan non hayati seperti di Perairan Pedalaman hingga ke Zona Ekonomi Eksklusif Indonesia atau batas wilayah laut yang ditentukan. 
Sumberdaya hayati laut yang berpotensi besar adalah perikanan. Keadaan terakhir ini menunjukkan bahwa eksplorasi dan eksploitasi sumber perikanan di Aceh pada dasarnya meningkat dengan sangat signifikan. Akan tetapi usaha eksploitasi dan eksploitasi di laut Aceh dipengaruhi oleh tindakan illegal fishing yang merugikan nelayan atau masyarakat nelayan (Adwani, et.al., 2015: 19).

Penangkapan ikan ilegal sering dilakukan oleh kapal-kapal asing yang merusak sumber daya ikan dan lingkungan. Secara nasional dan internasional bahwa lingkugan tersebut sangat penting dilindungi.

Penyadaran secara internasional dan nasional tentang status laut dan lingkungan hidup sebagai suatu kesatuan yang berhubungan dan menyeluruh telah menimbulkan format dan cara internasional yang memungkinkan keikutsertaan secara internasional memasuki batas kedaulatan negara untuk menata kemanfaatan dan pengelolaan elemen lingkungan yang terdapat dalam daerahnya, dan juga wilayah lautnya (Putra, 2005: 10).

Suatu negara mempunyai hak berdaulat, bahwa di laut wilayah suatu negara mempunyai kedaulatan penuh, namun kedaulatan tersebut mempunyai keterbatasan di laut wilayah yaitu dibatasi dengan kewajiban untuk member kepastian hak lintas damai dapat dilaksanakan oleh kapal-kapal asing (Kusumaatmadja dan Agoes, 2004: 173).

Kapal-kapal ikan asing dapat melalukan lintasan di laut suatu Negara dengan lintasan yang damai terutama di laut wilayah, tetapi kapal ikan asing tidak boleh menangkap ikan tanpa izin di perairan Zona Ekonomi Eksklusif (ZEE), namun banyak kapal asing yang menangkap ikan di ZEE, sehingga Pemerintah Daerah melakukan tugasnya untuk menegakkan hukum dan sebagian kapal ikan asing yang melanggar ditangkap untuk proses hukum.

Kapal-kapal asing mempunyai hak untuk lintas damai di laut wilayah. Karena itu lintasan merupakan lintasan damai sepanjang tidak merusak ketertiban, keamanan dan kedamaian negara pantai. Lintasan dianggap mengganggu kedamaian negara pantai, apabila kapal-kapal di laut wilayah melaksanakan kegiaan yang menimbulkan pencemaran dan menangkap ikan secara ilegal atau yang tidak sah (Anwar, 1998: 25). Menanggapi tindakan penangkapan ikan ilegal terutama oleh pihak kapal asing memerlukan tindakan nyata dari Pemerintah. Dalam hal ini Pemerintah Daerah Aceh bertanggung jawab melakukan tindakan hukum bagi pencegahannya pelanggaran hukum di wilayah laut.

Secara umum laut wilayah sebagai suatu zona laut yang berposisi sepanjang pantai suatu negara terletak dalam kekuasaan negara tersebut (Kusumaatmadja, 1996: 130). Di laut tersebut nelayan asing dilarang menangkap ikan, kecuali nelayan nasionalnya sendiri sesuai izin. Pada laut wilayah negara-negara dapat membuat ketentuannya untuk mengurangi, mencegah dan mengelola penangkapan ikan serta perusakan laut oleh kapal luar atau asing, namun negara pantai tidak menghambat hak lintas yang damai kapal-kapal asing (Koers, 1997: 27). Kapal-kapal asing yang berlayar di perairan suatu negara pada umumnya wajib dilayari secara damai bahwa kapal-kapal tersebut berlayar dengan tidak melakukan kegiatan apapun yang bertentangan dengan pelayaran yang aman dan damai (Adwani, 2001: 3).

Pada prinsipnya laut mempunyai banyak kegunaan, seperti untuk menangkap ikan, berlayar, sumber hayati lainnya. Karena itu negara mempunyai kewenangan dan bertanggung jawab untuk mengatur atau melindungi lingkungan laut dan sumber kekayaannya dari tindakan-tindakan yang merusaknya.

Bermacam-macam sumber daya alam hayati dalam arti jumlah, jenis, dan keunikannya meningkatkan sistem pendorong kehidupan. Dalam hal demikian, maka perlindungan terhadap bermacam-macam sumber kekayaan hayati ikan dan ekosistemnya dilakukan atas dasar hukum (Silalahi, 2001: 113).

Wewenang-wewenang yang dimiliki Negara pantai di laut wilayahnya antara lain, yaitu : 
1. Pengawasan di bidang duane, bea dan cukai;

2. Wewenang terhadap kapal-kapal asing;

3. Hak untuk menangkap ikan; hak-hak untuk mendirikan zona pertahanan;

4. Wewenang untuk melaksanakan kegiatankegiatan pengawasan (pengawasan, penangkapan kapal-kapal yang melanggar ketentuan-ketentuan negara-negara pantai);

5. Hak pengejaran seketika (Mauna, 2009: 376377).

Negara-negara pantai berdasarkan kewenangan yang dimilikinya dapat mengambil langkah-langkah yang diperlukan. Berkenaan dengan yang ada di daerah, maka Pemerintah daerah bertugas untuk menjalankan tindakan hukum terhadap pelaku penangkapan ikan secara tidak sah berdasarkan hukum yang berlaku. Karena itu pihak dinas terkait seperti Dinas Kelautan dan Perikanan menangkap kapal pelaku pelanggaran hukum di laut yang berdasarkan hukum, namun ketentuan hukum yang khusus belum terbentuk.

Kepala Bidang Pengawasan Dinas Kelautan dan Perikanan Provinsi Aceh, yaitu Zulkarnen, bahwa menyikapi kevakuman hukum tentang illegal fishing, pihak DKP Propinsi Aceh mendasarkan pada peraturan yang berkaitan dengan kegiatan mengawasi sumber perikanan, peraturan-peratuan tersebut diantaranya, adalah:

a. Undang-Undang RI Nomor 31 Tahun 2004 tentang Perikanan;

b. Undang-Undang RI Nomor 45 Tahun 2009 tentang Perubahan atas Undang-Undang RI Nomor 31 Tahun 2004;

c. Undang-Undang RI Nomor 27 Tahun 2007 tentang Pengelolaan Wilayah Pesisir dan Pulau Kecil;

d. Undang-Undang RI Nomor 1 Tahun 2014 tentang Perubahan atas Undang-Undang RI Nomor 27 Tahun 2007;

e. Peraturan Menteri Kelautan dan Perikanan Nomor 18/Permen-KP/2013 tentang Perubahan ketiga atas Permen-KP Nomor
Per.02/Men/2011 tentang jalur penangkapan ikan dan alat bantu Penangkapan Ikan di wilayah Pengelolaan Perikanan negara RI. (Zulkarnain, Kepala Bidang Pengawasan DKP Provinsi, Wawancara, tanggal 20 Juni 2016).

Berdasarkan aturan tersebut di atas dapat dipahami bahwa para aparatur pemerintah banyak terbantu dalam merespon kekosongan ketentuan terkait dengan illegal fishing. Walaupun demikian peraturan tersebut pada dasarnya lebih banyak membicarakan masalah pengawasan tentang illegal fishing terutama tentang pemakaian alat tangkap yang dilarang oleh undang-undang, sementara itu pengaturan khusus tentang pengawasan terhadap illegal fishing itu belum ada (Zulkarnain, Kepala Bidang Pengawasan DKP Provinsi Aceh, Wawancara, tanggal 22 Juni 2016).

Oleh karena belum adanya ketentuan khusus, maka hal tersebut menimbulkan akibat bahwa sulitnya penanggulangan penangkapan ikan secara ilegal yang menyebabkan penangkapan ikan ilegal terus terjadi, walaupun mengalami pengurangan. Dengan demikian pencegahan selama didasarkan pada aturan yang sedang berlaku selain aturan khusus.

The biggest obstacle is the existence of the regulatory region that has not yet been set up about illegal fishing. Local Government in carrying out its tasks to the prevention of illegal fishing refer only to provisions that exist. Because be has been no specific provision set obaut solving fishing illegally (Adwani, 2016: 4).

Potensi laut pada dasarnya dapat dimanfaatkan dengan terlebih dahulu dilakukan penelitian untuk memahami potensi tersebut. Dengan cara tersebut didapatkan keterangan entang karakteristik kondisi kelautan di daerah seperti tentang biota laut, serta berkenaan dengan perikanan dan pelayaran (Rizal, 2010: 3).

Laut pada dasarnya mempunyai banyak sumber daya alam, misalnya biota laut dan ikan telah dilakukan pengaturan-pengaturannya (Adwani, 2017: 188). Aturan-aturan tersebut sebagai aturan hukum 
laut nasional dan internasional. Untuk itu laut dengan sumber dayanya yang banyak dapat digunakan secara bermanfaat dan pemerintah daerah dapat mengeluarkan aturan pelaksanaannya dan perlindungannya.

Berkenaan dengan hal tersebut negara-negara pantai diwajibkan untuk melindungi sumber kekayaan alam tersebut dari menangkap ikan secara berlebihan atau dari tindakan perusakan. Tentu hal tersebut merusak sumber daya laut, untuk itu diperlukan usaha pelestarian, pemeliharaan atau pencegahan dengan melakukan pengaturan guna memudahkan penanggulangannya.

Dalam rangka melakukan pencegahan, Pemerintah daerah menjalankan kewenangannya guna perlindungan kekayaan ikan di wilayah lautnya. Akan tetapi meskipun telah dilakukan tindakan perlindungan, namun faktanya perlindungan tersebut belum terwujud sebagaimana mestinya (Adwani, 2011: 193).

Bilamana penangkapan dilakukan sesuai dengan taraf yang ditentukan, maka pemerintah daerah dan pusat membuat aturan yang adil guna kapal ikan atau nelayan dapat memanfaatkannya dan menguntungkan bagi tetap adanya surplus sumber perikanan di laut (Diantha, 2005: 38).

Berdasarkan hal tersebut dapat dipahami, guna keseimbangan kekayaan hayati bagi generasi selanjutnya, maka perlindungan tersebut sangat penting bagi kehidupan manusia. Hal tersebut merupakan tanggung jawab pemerintah untuk melakukan langkah-langkah yang patut, termasuk menerapkan hukuman bagi pelanggar hukum di laut, karena pelanggaran itu merusak sumber kekayaan ikan di laut tersebut, sehingga sangat diperlukan pemberian sanksi bagi pelanggarnya dan karena itu diperlukan aturan tertentu atau khusus.

Dewasa ini belum adanya aturan khusus tentang illegal fishing salah satu penyebabnya adalah karena ada peraturan lain yang sedang dalam proses dan dirasakan lebih penting. Terkait dengan malasah illegal fishing bahwa Pihak DPR Aceh mengaku belum pernah menerima pengaduan dari masyarakat (nelayan), atau bahkan permohonan, sehingga dirasakan mendesak untuk dikeluarkannya qanun tentang illegal fishing. Memang aspirasi dari masyarakat sebagai salah satu cara supaya suatu Perda (Qanun) bisa diprioritaskan untuk dibentuk. Walaupun demikian adanya peraturan bupati/walikota, telah menunjukkan bahwa pemerintah telah mengambil langkah yang tepat dalam menanggulangi kasus illegal fishing tersebut.

Di sisi lain belum adanya aturan khusus disebabkan oleh faktor belum terlibatnya seluruh stakeholder saat melakukan pengawasan dalam penanggulangan terhadap kasus illegal fishing. Contohnya pihak DPR Propinsi kurang terlibat saat penindakan terhadap kasus pelanggaran tersebut. Karena itu pula mengakibatkan informasi strategis tidak terbahas dalam rancangan undang-undang oleh pihak yang berwenang untuk melahirkan regulasi tentang illegal fishing. Akan tetapi di beberapa daerah telah berjalan dengan baik bentuk koordinasi antara stakeholder, hal tersebut merupakan langkah awal bagi mewujudkan terbentuknya Qanun Illegal Fishing, seperti yang dilakukan oleh pihak Pemerintahan di Kabupaten Aceh Utara.

Qanun yang dibahas oleh Pemerintah Kabupaten Aceh Utara dengan DPRK saat itu adalah Qanun yang berkaitan dengan pencegahan penangkapan ikan secara ilegal. Dalam kaitan ini bahwa untuk menanggulangi penangkapan ikan secara ilegal tersebut umumnya didasarkan kepada Undang-Undang Nomor 31 Tahun 2004 tentang perikanan dan Qanun Provinsi Aceh Nomor 7 Tahun 2010 tentang Pengelolaan Sumber Kekayaan laut (Usman, Kepada Bidang Pengawasan Dinas Kelautan dan Perikanan Kabupaten Aceh Utara, Wawancara, tanggal 22 Juni 2016).

Sehubungan dengan persoalan kebijakan khusus, maka penanggulangan illegal fishing belum maksimal, termasuk di Aceh Utara. Dalam kaitan tersebut bahwa kawasan laut Aceh Utara merupakan 
kawasan laut yang banyak sumber ikannya, sehingga kapal-kapal ikan baik kapal asing dan nasional menangkap ikan dengan cara tidak mengindahkan aturan yang ditetapkan, bahwa sebagian dari kapalkapal tersebut menangkap ikan dengan pukat harimau sebagai alat-alat penangkapan yang dilarang. Oleh karena itu, diperlukan sikap Pemerintah Daerah untuk melakukan pengaturan dan menindak kapal-kapal yang melanggar, namun kadangkala kurang mendapat respon dari Pemerintah Daerah sehubungan adanya tolak tarik kepentingan. Keadaan tersebut menyebabkan penanganan pencegahan illegal fishing kurang tertangani dengan baik. Akan tetapi dapat dikatakan bahwa dalam beberapa bulan lalu sudah ada pembahasan Qanun tentang penanggulangan penangkapan ikan secara ilegal tersebut (Bakhtiar, Wakil Kepala Komisi B DPRK Aceh Utara, Wawancara, tanggal 23 Juni 2016).

Terkait illegal fishing bahwa hal tersebut telah menjadi perhatian serius DPRK Aceh Utara. Hal tersebut dikarenakan banyaknya persoalan yang disampaikan dan dihadapi oleh para nelayan, sehingga pihak DPRK menyepakati untuk membahas dan menyelesaikan suatu kebijakan berupa Qanun tentang illegal fishing, guna adanya dasar hukum yang khusus. bilamana terdapat ketentuan khusus, maka pihak-pihak yang melanggar dapat dihukum dengan hukuman tegas. Lahirnya aturan tersebut juga menjadi harapan para nelayan, supaya penanganan lebih efektif, di samping itu mekanisme pelaporan yang selama ini dilakukan oleh nelayan direspon secra positif (Hamzah, Ketua Legislasi (Panleg) DPRK Aceh Utara, Wawancara, tanggal 24 Juni 2016).

Keadaan sebaliknya, bahwa angka kasus illegal fishing yang dilakukan oleh nelayan asing menurun demikian rupa di Kabupaten Aceh Barat. Penangkapan terakhir di Aceh Barat terhadap kapal nelayan asing (4 unit kapal Thailand) terjadi pada tahun 2013. Keadaan tersebut bahwa di Aceh Barat tidak mudah dimasuki oleh nelayan asing karena dipengaruhi oleh keadaan geografis laut (Helmy,
Bagian Pengawasan DKP Aceh Barat, Wawancara, tanggal 19 Juli 2016).

Berkenaan dengan kebiasaan masyarakat nelayan lebih cenderung menggunakan alat tangkap yang dilarang aturan yang berlaku, maka hal ini menjadi suatu permasalahan dalam penanggulangan penangkapan ikan tidak sah, seperti pukat harimau atau trawl yang sebagian digunakan oleh nelayan Aceh Barat, dan disisi lain juga dilakukan illegal fishing di negara lain oleh nelayan tersebut (Ferdiansyah, Panglima Laot Kabupaten Aceh Barat, Wawancara, tanggal 20 Juli 2016).

Bentuk aktivitas lain sehubungan penganggulangan illegal fishing, antara lain sosialisasi peraturan perundang-undangan melalui tatap muka, poster dan pamplet himbauan, dan pembentukan dan pembinaan Kelompok Masyarakat Pengawas (Pokmaswas) serta patrol laut (Usman, Kepala Bidang Pengawasan Dinas Kelautan dan Perikanan Kabupaten Aceh Utara, Wawancara, tanggal 23 Juni 2016).

Berdasarkan hal yang dikemukakan di atas, bahwa sosialisasi dan atau diseminasi dilakukan oleh pihak DKP Propinsi terkait dengan penggunaan alat tangkap dan juga hal yang berkenaan dengan masalah penangkapan ikan tidak sah kepada Panglima Laot dan para nelayan yang bekerjasama dengan Lanal, Polair dan DPRK. Diseminasi masalah illegal fishing itu diutamakan ke kabupaten yang memiliki jumlah kasus illegal fishing yang terbanyak seperti Aceh Utara, Aceh Barat Daya dan daerah Aceh Timur. Setelah itu ke daerah Bireuen, Pidie dan ke lain daerah (Zulkarnain, Kepala Bidang Pengawasan DKP Provinsi Aceh, Wawancara, tanggal 20 Juni 2016).

Mengacu kepada hal tersebut bahwa masalah illegal fishing telah mendapat perhatian pihak terkait, baik Pemerintah Daerah, Panglima Laot, TNI AL dan para nelayan. Akan tetapi untuk menanggulangi hal tersebut yang lebih efektif diperlukan tindakan hukum yang tegas dan adanya ketentuan khusus. 
B. Koordinasi Antara Institusi Terkait Dengan Panglima Laot Dalam Menanggulangi PenangKapan Ikan Secara Ilegal

Berkenaan dengan kejadian-kejadian yang terjadi di kapal asing yang berada dalam wilayah perairannya, suatu negara tidak langsung menerapkan yurisdiksinya, akan tetapi bilamana sebuah kapal telah memasuki wilayah perairannya, maka terhadap kapal tersebut dapat diberikan sanksi hukum dari negara yang berdaulat tersebut (Thontowi dan Iskandar, 2006: 186).

Suatu gejala bahwa terjadi penangkapan ikan yang berlebihan atau pencurian ikan, dan bahkan tindakan salah lainnya yang tidak saja mengancam kepentingan pembudi daya ikan, nelayan, usaha perikanan nasional, dan iklim industri, bahkan menimbulkan kerugian bagi negara (Lestari, 2014: 273).

Sehubungan dengan hal tersebut, dalam menanggulangi kegiatan illegal fishing bahwa pemerintah daerah mengsertakan para masyarakat nelayan terutama Panglima Laot dan stakeholder. Disamping itu juga dalam patroli yang dilakukan di wilayah laut perbatasan dengan batas negara lain dan atau di laut lepas yang saling berbatasan. Di sisi lain dilaksanakannya patroli bersama antara Airud, TNI AL, DKP di laut teritorial dan perbatasan dalam rangka melakukan pengawasan di laut. Dalam hal ini prioritas lokasi patroli lebih ke wilayah Aceh Timur, Aceh Utara, Sabang, Melaboh, kemudian wilayah Pidie dan daerah Aceh lainnya. Namun yang sangat prioritas Aceh Timur dan Aceh Utara.

Fungsi pengawasan dilakukan oleh pihak terkait dan di Aceh Utara dilakukan kerjasama secara rutin, seperti antara Lanal, Polair, DKP dan Panglima laot, bahkan dengan para nelayan. Dalam hal ini telah dilakukan suatu kesepatakan antara Pemerintah daerah dengan panglima laot dan nelayan dalam rangka pengawasan dan menginformasikan pelanggaran hukum di laut dari pihak nelayan kepada pihak terkait, sehingga terjalin hubungan yang baik antara pihak Pemerintah dengan nelayan (Asnawi,
Sekretaris Panglima Laot Kabupaten Aceh Utara, Wawancara, tanggal 23 Juni 2016). Dipahami bahwa pengawasan terhadap sumber kekayaan ikan itu sangat penting guna kelestarariannya.

Pengawasan dilakukan di setiap wilayah oleh Lanal dan Polisi laut, Dinas Kelautan dan Perikanan (DKP) dan Lanal, bahwa pihak terkait seperti Pol Air, Lanal berpatroli sesuai jadwal yang ditetapkan, di samping itu pihak DKP mengawasi menurut jadwalnya secara terpadu dengan Pol Air, misalnya sebulan sekali. Terkait dengan hal tersebut terdapat beberapa unsur penting dalam pelakasaan tugas DKP, yaitu:

1. Sarana dan prasarana dan kapal pengawasan patrol;

2. Penyidik Pengawai Negeri Sipil (PPNS);

3. Penyidikan didukung tempat karantina, dan dititipkan ke Airud.

Pencegahan penangkapan ikan secara ilegal dijalankan secara terpadu dari instansi terkait, seperti Badan kordinasi keamanan Laot (Bakorkamla), dibantu dengan alat pendeteksian keamanan laut di Ujung Bateu serta di Kantor Syahbandar terdapat kesatuan Penjagaan Laut dan Pantai (KPLP). Di samping itu terdapat dukungan alat komunikasi di laut dan pelabuhan bagi penanggulangan terhadap tindakan kapal-kapal ikan asing.

Pada dasarnya Pemerintah Daerah melakukan proses pencegahan penangkapan ikan secara tidak sah itu dijalankan oleh instansi-instansi terkait yang didukung patroli-patroli, namun pentingnya peran para nelayan, karena pada saat para nelayan melihat kapal asing sedang menangkap ikan tidak sah lalu nelayan melakukan pelaporan kepada Panglima Laot dan melanjutkan hal itu kepada Pol Air atau Lanal guna ditindaklanjuti (Bustamam, Panglima Laot Provinsi Aceh, Wawancara, tanggal 25 Juni 2016).

Penegakan hukum di laut terhadap penangkapan ikan ilegal dilakukan kerjasama antara instansi terkait. Hal tersebut sangat penting guna terjalin kerjasama dan saling membantu untuk menanggulangi pelanggaran dalam penangkapan ikan 
yang marak terjadi di wilayah laut. Dengan kerjasama atau koordinasi antara instansi terkait dan sesuai dengan jadwal yang disepakati, maka dapat mewujudkan hasil yang maksimal. Namun demikian karena terdapat persoalan kendala yang dihadapi, sehingga kordinasi tersebut masih sangat penting ditingkatkan.

Perlindungan sumber kekayaan ikan umumnya dilakukan kerjasama, dan dengan mengikutsertakan Panglima Laot. Panglima Laot berperan memberikan informasi bilamana terdapat penangkapan ikan ilegal (Adwani, 2011: 193). Oleh karena itu koordinasi dan kerjasama beberapa aparatur terkait sangat perlu dukung mendukung dalam penanggulangan penangkapan ikan secara ilegal, yang melibatkan pihak Panglima Laot sebuah keniscayaan karena pengalaman dan keberadaan Panglima Laot di lapangan walau tanpa alat komunikasi yang modern, tetapi memberikan hasil yang sangat mendukung dan berarti.

Dengan demikian, penanggulangan penangkapan ikan secara ilegal dilakukan oleh para penegak hukum di laut. Sesuai kewenangan yaitu kewenangan itu dimiliki oleh Pol Air, Lanal, Dinas Kelautan dan Perikanan. Instansi inilah yang betugas menegakkan hukum di laut, sedangkan Panglima Laot membantu member informasi kepada pihak yang berwenang supay dapat mengkordinir bagi penegakan hukum di laut (Jakfar, Sekretaris Panglima Laot, Kabupaten Pidie, Wawancara, tanggal 27 Juni 2016).

Peran Panglima Laot dari masing-masing kabupaten berbeda, ada yang memiliki wewenang penuh dan di beri kepercayaan untuk melakukan pengawasan terhadap illegal fishing. Namun ada daerah yang merasa Panglima Laot hanyalah formalitas semata, sehingga tidak memahami tupoksi dalam melaksanakan pengawasan bersama Pol Air. Daerah Lhokseumawe peran Panglima Laot sangat formalitas, demikian juga di Pidie. Akan tetapi di Aceh Utara Panglima Laot sangat berperan dalam melakukan pengawasan, dan memonitoring illegal fishing, bahkan ikut membantu menangkap pelaku illegal fishing bersama Pol Air.

Selama ini pihak Pemda saling berkoordinasi dengan pihak-pihak yang terkait dengan kasus illegal fishing. Seperti yang dilakukan oleh Dinas Kelautan dan Perikanan (DKP) saat terjadi kasus illegal fishing di laut Aceh, DKP berkoordinasi dengan pihak aparat seperti Polres, Danlanal dan Airud serta berkoordinasi dengan masyarakat nelayan, Pawang Laot dan Panglima Laot.

Selain itu seperti yang dilakukan oleh Bupati Aceh Barat dengan merujuk pada Permen Nomor 2 Tahun 2015 tentang Larangan Penggunaan Ikan Trawl dan Seine Net, membentuk tim terpadu patroli pengawasan dengan SK dari Bupati. Tim tersebut antara lain Bupati Aceh Barat, Kapolres, Dandim, Kadis DKP, Wakapolres, Kabag OPS, Kepala Bappeda, Sekretaris DKP, Kabid Pengawasan, Kasat Pol Air, Dan Pos TNI AL, Kabid Perikanan Tangkap, Kasi Pengawasan, Kasi Pengolahan, Kabag Binmas, Kabag Reskrim, Staf DKP 5 orang, Unsur Pol Air 6 orang, Anggota TNI AL 5 orang, Unsur Dandim 2 orang, Staf Dishubtel 2 orang, Unsur Satpol PP dan WH 1 orang, Unsur Panglima Laot 2 orang (T. Helmy, Bidang Pengawasan Dinas Kelautan dan Perikanan Aceh Barat, Wawancara, 21 Juli 2016).

Tim tersebut bertugas melakukan koordinasi kegiatan pengawasan, pengendalian serta penertiban alat tangkap yang tidak ramah lingkungan di Kabupaten Aceh Barat. Selain itu juga bertugas melakukan pengawasan secara rutin terhadap alat tangkap di perairan Kabupaten Aceh Barat, melakukan sosialisasi dan penindakan hukum bagi nelayan yang menggunakan alat tangkap ikan yang tidak ramah lingkungan dan melakukan pemusnahan terhadap alat tangkap yang dilarang guna terpelihara lingkungan dan sumber perikanan.

Di samping itu pengawasan dan penanggulangan penangkapan ikan tidak sah dijalankan Pemerintah Kota Sabang yang bekerjasama dengan instansi terkait, bahkan membentuk kelompok pengawasan 
masyarakat dengan maksud bahwa jika diketahui ada kapal yang melanggar hukum, mereka melaporkan hal itu ke Panglima Laot untuk diteruskan pihak terkait. Peran kelompok pengawas itu dapat membantu pemerintah daerah dan mengatasi kendala yang terjadi (Saifullah, Kepala Dinas Kelautan dan Perikanan Kota Sabang, Wawancara, tanggal 28 Juli 2016).

Bicara tentang penegakan hukum illegal fishing khususnya berkenaan dengan pelanggaran oleh pelaku bernuansa internasional ada terjadi tetapi mulai berkurang, namun terkait masalahnya dengan terbatasnya fasilitas kapal dan anggota yang dimiliki DKP. Dalam hal ini DKP telah membentuk sejumlah kerjasama dengan instansi-instansi pemerintah terkait, seperti dengan departemen pertahanan (KEMENHAN). Hal ini yang dibuktikan dengan dilakukan penandatanganan kesepakatan antara Kemenhan dengan DKP tentang penguatan pengawasan sumber daya kelautan dan perikanan (Aref, Kasubdit Penyelidikan Dirjen Pengawasan Sumberdaya Kelautan dan Perikanan, Departemen Kelautan dan Perikanan Indonesia, Wawancara, tanggal 20 Agustus 2016).

Kejasama pemberantasan illegal fishing khusunya illegal unregulated dan illegal unreported disepakati oleh instansi pemerintah untuk ditingkatkan. Menteri Kelautan dan Perikanan Susi Pudjiastuti dan Menhan Ryamizard Ryacudu menandatangani kesepakatan bersama, bahwa hal itu sebagai upaya Pemerintah RI untuk menguatkan pengawasan kelautan dan perikanan. Kesepakatan tersebut juga sebagai wujud komitmen pemerintah di wilayah pengelolaan perikanan negara Republik Indonesia (WPPNRI) karena telah mengakibatkan kerugian negara akibat pemanfaatan sumber daya perikanan dan kelautan secara tidak sah, sebagaimana dilakukan kapal perikanan asing. Hal demikian berkaitan dengan kedaulatan RI atas wilayah laut dan ZEE ditegakkan guna mengurangi atau mencegah pelanggaran hukum Indonesia di laut.
Kerjasama tersebut termasuk rencana pengadaan pesawat udara negara jenis Marine Surveillance Aircraft (MSA), dengan kemampuan endurance 8-10 jam terbang supaya perairan Indonesia dapat diawasi secara optimal. Pesawat tersebut juga dilengkapi dengan Monitoring Control Surveillance (MCS) perikanan, instrumen pengawasan saat kegiatan penangkapan (while fishing), radar, Forward Looking Infra Red (FLIR), AIS Transporder data link dari pesawat ke kapal pengawas (Aref, Kasubdit Penyelidikan Dirjen Pengawasan Sumberdaya Kelautan dan Perikanan, Departemen Kelautan dan Perikanan Indonesia, Wawancara, tanggal 20 Agustus 2016).

Kerlibatan Kemenhan dalam kerjasama tentang asistensi pengadaan pesawat tersebut tidak terlepas dengan pengadaan sejumlah fasilitas, sehingga sejumlah fasilitas dan pelaksanaan murni harus dijalankan oleh Kemenhan. Posisi Kemenhan dalam proses kegiatannya akan memberikan asistensi pengadaan pesawat udara negara dengan menerbitkan register number temporary, special flight permit, dan penerbitan certificate of airworthiness. Dengan demikian kerjasama antar instansi semakin meningkat dan peralatan yang dibutuhkan dapat diadakan.

Di samping itu, kerjasama bidang penguatan SDM pengawas diadakan antara DKP dengan Polri melalui diklat polisi khusus PWP3K (pengawas pengelolaan wilayah pesisir dan pulau-pulau kecil dengan kewenangan polisi khusus). Pengawasan dalam menciptakan kelestarian sumber daya kelautan dan perikanan yang dilakukan DKP pada dasarnya memperkuat DPK dalam pengawasan atas dasar kemitraannya dengan Polisi atau Pol Air.

Dalam lingkup internal DKP sendiri juga mengadakan kemitraan dengan Departemen perhubungan khususnya Dirjen ASDP dalam bidang Basic Safety Training untuk meningkatkan kemapuan teknis awak kapal pengawas (AKP). Dalam pelatihan para peserta dibekali dengan materi Elementary First 
Aids (EFA), Personal Survival Technic (PST), Personal Safety Social Resposibility (PSSR) serat Fire Fighting (FF). Kegiatan semacam ini diharapkan dapat mewujudkan keselamatan pelayaran kapal pengawas baik yang ada dilingkup DKP maupun Dephub untuk mewujudkan keselamatan pelayaran kapal pengawas dalam memberantas illegal fishing.

Berdasarkan hal tersebut bahwa tindakan untuk menanggulangi penangkapan ikan tidak sah dilakukan, baik oleh Pemerintah Daerah maupun Pemerintah Pusat, yang didasari perlunya personil dan peralatan yang memadai. Dalam hal ini juga mengadakan pengawasan dan penindakan dengan cara kerjasama antar instansi dengan tujuan supaya adanya penguatan dalam fungsi penanggulangan penangkapan ikan ilegal guna pemeliharaan dan pelestarian sumber kekayaan ikan. Walaupun upaya pencegahan telah dilakukan demikian rupa, namun penanggulangan tersebut terwujud secara optimal.

\section{SIMPULAN DAN SARAN}

A. Simpulan

1. Pemerintah Daerah sangat berperan dalam menganggulangi penangkapan ikan secara ilegal (illegal fishing), bahwa dilakukan pengawasan oleh pihak terkait dan dan dikeluarkannya peraturan Peraturan Daerah dan Peraturan Bupati terkait masalah pengawasan terhadap masalah alat tangkap dan pelestarian sumber perikanan, namun belum ada aturan khusus. Pemerintah secara berkesinambungan terus membangun sejumlah fasilitas pendukung penegakan hukum, seperti pos-pos keamanan disejumlah titik terluar batas Indonesia serta peran serta $\mathrm{Pol}$ Air dan TNI AL yang secara berskala melakukan patroli rutin di sejumlah wilayah terluar atau yang paling sering terjadi kegiatan illegal fishing diperaian laut, namun penanggulangannya masih perlu ditingkatkan.

2. Pemerintah Daerah dinilai proaktif dalam menanggulangi masalah penangkapan ikan secara ilegal (illegal fishing), terutama dengan dilakukannya kerjasama antara instansi terkait, seperti DKP, Pol Air dan TNI AL serta Panglima Laot yang berperan memberi informasi kepada pihak terkait. Disisi lain dibentuknya pokmaswas (kelompok masyarakat pengawas) yang terdiri dari masyarakat nelayan yang ketuai oleh Panglima Laot dan berbagai SK Bupati/Walikota tahun 2016 terkait dengan pengawasan alat tangkap yang tidak ramah lingkungan (illegal fishing), yang melibatkan stakeholder, termasuk perwakilan dari Panglima Laot. Namun bentuk koordinasi dengan berbagai perangkat daerah yang bekerja sama dengan Angkatan Laut dan Panglima Laot di daerah, masih belum menyentuh secara khusus terhadap kasus illegal fishing yang dilakukan oleh nelayan asing yang jelas mengganggu perekonomian masyarakat dan mengganggu stabilitas keamanan Negara, merusak sumber perikanan dan lingkungan laut. Pada dasarnya kerjasama antar instansi dan Panglima Laot telah menghasilkan, namun masih perlu ditingkatkan keefektifannya.

\section{B. Saran}

a. Disarankan agar Pemerintah Daerah dan Pusat dapat melahirkan regulasi yang mengatur tentang illegal fishing secara khusus yang mencakupi tentang UII (unregulated, unreported dan illegal fishing) sebagaimana yang sudah dijelaskan dalam Undang-Undang tentang Perikanan. Selain itu Pemerintah Daerah juga perlu membuat Qanun khusus terkait illegal fishing mengingat secara geografis letak laut Aceh sangat rentan terjadinya kasus illegal fishing yang dilakukan oleh nelayan asing.

b. Pemerintah diharapkan tetap dan terus menerus melakukan pengawasan secara berkala untuk menanggulangi penangkapan ikan secara ilegal oleh kapal-kapal asing dengan meningkatkan 
koordinasi antara instansi terkait. Agar bentuk pengawasan ini berjalan secara efektif dan tuntas, hendaknya pemerintah juga menyediakan dana khusus atau memfasilitasi kerja yang selama ini sudah dilaksanakan oleh pihak terkait, seperti alat transportasi yang memadai, alat komunikasi yang sesuai dengan kebutuhan selama pengawasan dilakukan, SDM yang berkualitas sesuai dengan kualifikasi yang dibutuhkan dan regulasi yang memiliki efek jera bagi pelaku illegal fishing (nelayan asing).

\section{DAFTAR PUSTAKA}

\section{Buku}

Adwani, 2017, Hukum Laut Internasional, Banda Aceh, Fakultas Hukum Unsyiah Press.

Agoes, Etty R., 1997, Konvensi Hukum Laut 1982 Masalah Pengaturan Hak Lintas Damai Kapal Asing, Bandung, Abardin.

Anwar, Chairul, 1998, Horizon Baru Hukum Laut Internasional Konvensi Hukum Laut Internasional, Jakarta, Djambatan.

Diantha, I Made Pasek, 2005, Zona Ekonomi Eksklusif Indonesia Berdasarkan Konvensi Hukum Laut PBB 1982, Bandung, Mandar Maju.

Koers, Albert W., 1997, Konvensi Perserikatan BangsaBangsa Tentang Hukum Laut, Terjemahan Rudi M. Rizki dan Wahyuni Bahar, Yogyakarta, Gadjah Mada University Press.

Kusumaatmadja, Mochtar, 1996, Hukum Laut Internasional, Bandung, Binacipta.

Kusumaatmadja, Mochtar, 2004, Konsep-Konsep Hukum dalam Pembangunan, Bandung, Alumni.

Mauna, Boer, 2009, Hukum Internasional Pengertian Peranan dan Fungsi dalam Era Ginamika Global, Bandung, Alumni.

Putra, Ida Bagus Wyasa, 2005, Hukum Lingkungan Internasional, Perspektif Bisnis Internasional, Bandung, Refika Aditama.
Silalahi, M. Daud, 2001, Hukum Lingkungan dalam Sistem Penegakan Hukum Lingkungan Indonesia, Bandung, Alumni.

Thamrin, Tanty S. Reinhart, Penegakan Hukum Laut terhadap Illegal Fishing, Bahan RTD Penegakan Hukum Maritime terhadap Praktik Illegal Fishing di Indonesia, Lemhanas-RI, 16 Juni 2016.

Thontowi, Jawahir, 2005, Hukum Internasional di Indonesia Dinamika dan Implementasi dalam Beberapa Kasus, Yogyakarta, Madyan Press.

Thontowi, Jawahir, 2006, Hukum Internasional Kontemporer, Bandung, Refika Aditama.

\section{Jurnal}

Adwani, 2016, "Local Government Role in the Solving of Catching Fish Illegally in Aceh Region”, Jurnal Dinamika Hukum, Vol. 16, No. 1. Adwani, 2011, "Perlindungan Sumber Daya Perikanan Laut Sebagai Bentuk Tanggung Jawab Pemerintah Daerah di Perairan Laut Wilayah Provinsi Aceh", Jurnal Media Hukum, Vol. 18, No. 2.

Lestari, Maria Maya, 2014, "Penegakan Hukum Pidana Perikanan di Indonesia Studi Kasus Pengadilan Negeri Medan”, Jurnal Ilmu Hukum, Vol. 3 No. 2.

\section{Makalah}

Adwani, "Pelaksanaan Yurisdiksi Territorial Terhadap Kapal-Kapal Perikanan Asing di Perairan Pedalaman Barat Aceh", Laporan Penelitian, (Dosen Muda), Universitas Syiah Kuala, Darussalam, 2001.

Agoes, Etty R., "Dimanakah Batas-Batas laut Kita", Makalah, Departemen Kelautan dan Perikanan, Jakarta, Desember 2000.

Rizal, Syamsul, "Peranan Pemodelan laut Pada Pembangunan Bidang Kelautan dan Perikanan Di Indonesia”, Pidato Pengukuhan Guru Besar, Universitas Syiah Kuala, Darussalam, 2010. 


\section{Konvensi, Undang-Undang dan Peraturan}

Konvensi Hukum Laut PBB 1982 tentang Hukum Laut (UNCLOS).

Undang-Undang Nomor 23 Tahun 2014 tentang Pemerintah Daerah

Undang-Undang Nomor 11 Tahun 2006 tentang Pemerintah Aceh

Undang-Undang Nomor 45 Tahun 2009 tentang Perikanan

Peraturan Menteri Kelautan dan Perikanan RI Nomor 18/Permen-KP/2013 tentang Perubahan Ketiga Atas Peraturan Menteri Kelautan dan Perikanan Nomor Per.02/Men/2011 tentang Jalur Penangkapan Ikan dan Penempatan Alat Penangkapan Ikan dan Alat Bantu Penangkapan Ikan di Wilayah Pengelolaan Perikanan Negara RI 